\title{
Remuneration strategies related to Charles Handy's cultural typology: a case study in a small digital market business in remote work
}

\author{
Gabriel Guimaraes Morais, Etienne Cardoso Abdala1, Daisy Nascimento Rebelatto \\ ${ }^{1}$ University of São Paulo - USP, São Carlos School of Engineering, São Carlos, SP, Brazil.
}

How to cite: Abdala, E.C., Morais, G.G. and Rebelatto, D.N. (2021), “Remuneration Strategies related to Charles Handy's cultural typology: A case study in a small digital market business in remote work", Brazilian Journal of Operations \& Production Management, Vol. 18, No. 2, e20211194. https://doi.org/10.14488/BJOPM.2021.040

\begin{abstract}
Goal: This research intends to propose a remuneration system adjusted to remote work conditions in Pandemic context, considering the types of Charles Handy's Cultural Typology

Design / Methodology / Approach: The research developed in this study is qualitative and descriptive. For data collection, a questionnaire elaborated based in a validated protocol was applied to the director and other employees at the company as a Simple Case Study.

Results: According to the results, the Person Culture is the one most present at the Organization studied. The authors took into consideration the fact that the Task Culture is also greatly presented in the organizational culture of the company. The results indicate that the company would need to increase the share of variable remuneration in compliance with the more autonomous forms of work organization rules, as the home office way of work. The company also presents a good organizational climate, with a lot of collaboration and trust in the relations between its employees.

Limitations of the Investigation: the limitations of the study are related to the fact that it is not possible to generalize the results to other small companies, considering that the organizational culture of the studied company is unique if compared to other companies. Other limitations refer to the fact that the study presents an initial overview of a home office situation at the beginning of the pandemic context, and other considerations can be made later.

Practical implications: The company should seek to increase the variable portion on the payroll of its employees. Because the people that work at the company have great autonomy, working remotely and being able to choose work hours, adopting a system that prioritizes variable portion of the salary is important so that the workers feel motivates to produce more, seeking a higher remuneration. Otherwise, with a good level of fixed remuneration, the workers can become less productive and comfortable
\end{abstract}

Originality / Value: The research contributes to understand the remuneration strategies in new work contexts, especially in terms of the transition from presential work to home office in a digital market business.

Keywords: Remuneration Strategies; Cultural Tipology; Home Office.

\section{INTRODUCTION}

The global economic dynamics, attached to the ascension of new technologies, contributed in modifying the business environment, making it more complex in terms of competition and instability. In this way, in addition to a larger number of companies emerging

Financial support: None.

Conflict of interest: The authors have no conflict of interest to declare.

etienneabdala@hotmail.com

Received: 15 March 2021

Approved: 1 June 2021.

Editor: Syed Abdul Rehman Khan. 
in the market, the competitivity took on an important role inside the companies own organizational culture. In this scenario, the seek for high productivity and quality demanded by consumers, being that of a service or a product, demanded changes in business relations.

The conditions presented by the new sanitary context that the world faces since the beginning of 2020 took significant changes to the workspace. The main one being the work becoming remote, providing isolation as necessary to evade contamination by the new coronavirus. The home office consists of carrying out the work in an independent place of the employer 's installation. As of today, with the scenario put on by the coronavirus pandemic, is notable that this model of work has its advantages but also its challenges.

According to Vyas and Butakhieo (2021) before the pandemic there was some resistance and many questions about remote work. After the Covid epidemic 19, there was a motivation for a work organization focused in home office, and organizations started to adopt this work model very often. Certainly, remote work, despite not always perfect conditions of tranquility, allows flexibility, and can be considered a type of work organization that will be accepted and very used in the future.

The situation experienced by the world population changed radically after the beginning of the Covid 19 pandemic in several ways. This directly affected the work environment and these changes that emerged in a context of restricted traffic also impact the characteristics of the organizational culture of companies (Ancillo et al., 2020). When considering organizational changes in the work place, it is also necessary to reflect on the demands regarding remuneration and benefits policies.

In this way, it is interesting to analyze the relation between a company `s organizational culture adopted in remote work with the remuneration system employed, considering the main concepts of organizational cultures presents by Charles Handy. Reasoned in Handy`s study (Handy, 2003), an investigation about the correlation between the types of organization culture and remuneration systems spheres begun, developed by Russo et al. (2012). For this research, the priority of analysis was done amidst the pros and cons of fixed quotas and wage variables, comprehending the independences of organizational cultures of the companies and the choice of the remuneration system.

In this sense, this study's goal is to propose a remuneration system adjusted to remote work conditions, considering the types of culture of Charles Handy (1980). To collect data, four company employees were interviewed, through the application of questionnaire in an digital marketing company. The results indicated that the majority of wage components were previously adopted by the company are in agreement with what was proposed by Russo et al. (2012) for companies that fit the Person and Task Culture typologies.

\section{LITERATURE REVIEW}

There are many researches and publications about the organizational culture, values and remuneration system within the human resources management approach. However, the key authors for discussing the topic are generally Schein (1985), Hofstede (2001) in international publications and Freitas (2000) in national ones. The organizational culture subject comprises a wide range of concepts, and the main point of this research is its relationship with remuneration systems, especially considering the research by Charles Handy's typology (Handy, 1980) and Russo et al. (2012).

The organizational culture is comprehending as a set of habits, beliefs and shared values by the people that compose a group. For Schein (1985), a structuring of a model of organization culture begins as the owner of a company, in the beginning of its existence, started to mold its own relation with its employees, and the relation between them, according with its influence and personality.

According to Freitas (2000), the concept of 'Organizational Culture' became more utilized in the decade of 1980. At that time, large American companies were losing a significant quota of the global market to the new Japanese companies, marking an epoch of turbulence and instability to American companies. 
Schein (1985) separates the manifestation of cultural organization in three levels, according to how much each of theses levels is directly visible/perceptible in the perspective of someone who observes from the outside: at the first level, there are the visible aspects (symbols, messages, layouts), at the second level, shared values and beliefs by the group, and lastly, at the third level, the basic presumptions of each individual.

Hofstede (2001) identifies some dimensions whereby the organizational culture can be reflected inside of a company, according to the set practices and norms that compose it. First, the author addresses the dimensions as of individuality is treated inside of the company. An enterprise can value and encourage, for example, more individualized behavior, or more focused in group work or cooperation. Following, the hierarchical aspect must be observed, through of which it is possible to identify how distribution of power inside the company occurs. Lastly, the author presents the last dimension in which evaluates if the cultured is more inclined to "tougher" relationships or more soft ones, as well as the uncertainty degree inside the company and how much its employees feel comfortable or not with the hierarchical model proposed.

Ludolf et al. (2017) argues that the organizational culture is formed by a formal and an informal dimension. The informal part ends up creating its own hierarchy, a separate power structure and peculiar habits that causes the culture changes. This informality causes organizational change that will impact on an adjustment of the organizational culture, which in turn is constantly adapting. Thus, culture is incorporated into the organization and understood by the organizational actors. Ludolf et al. (2017) support that Schein (1985) strengthened the concept that culture is one of the major forces that impacts the social environment, with organizational culture being the true identity of a corporation

Several authors developed, over time, identification models of the Organization Culture adopted in each company. We will cite two of the main models that, still today, is source of analysis for the majority of studies done about the subject. According to Freitas (1991) the objective of these models is to be able to represent and generalize, through a methodology, the cultural typologies that can be found in each company, so that they man, through these spectra and standardizations, become object of study and analysis.

The main objective of Handy's (1980) cultural typology is demonstrate how the relation between coming power channels or exercised by the owners (or by the lack of management) and the body of works of a company will be reflected on the institutions as a whole. In Handy's model, it is observed how the hierarchical structure of power installs and, though it, as it is observed, by the company as unity(generalization), the power of who is in charge. Through this observation, Charles Handy pretends, with his model, to identify what are the effects and reactions of the established model in all body of workers in the company. According to Russo et al. (2012), even though the typological cultural model of Charles Handy had been developed in 2980, his work was validated and became base of study for important authors of this subject of Organizational Culture, such as Bourantas et al. (1990) and Gomide Júnior and Martins (1997)

The spectrums of Charles Handy's typological culture, that represent the way how the sensation and representation of power is inserted in the company, are divided into four Greek gods: Zeus, Apollo, Athena and Dionysius. According to Handy (1980), his objective, with the representation of the structures and the establishment of the spectrums of the organizational culture through the Greek gods, is to demonstrate and highlight how the workspace in which theses relations occurs is extremely creative and dynamical, and non-statical. With that, according to Russo et al. (2012), Handy pretends to demonstrate and remember, as an example, that it is improbable that the reality of the organizational culture present in a company can be framed into one of the spectrums presented by the author's typology. Charles Handy (1980) highlights, in truth, that various characteristics of different spectrums should be found in the same institution, that is, spectrums of several gods (power structures) will be acting at the same time in the company. However, the author also highlights that, in the end, some spectrums will have to stand out and, this way, showcase the main spectrum present in the environment.

Enlightened the general objectives of the typological model established/proposed by Charles Handy, it is possible, now, to explain what are and how are divided the spectra of Greek gods proposed by the author, the first spectrum is the culture of power, represented 
by Zeus, god of Olympus. This culture is characterized by a structure of power that organizes in a spider web, with power completely concentrated in the middle. In the companies that this spectrum stands out, those in command usually have strong influence in everyone around them. In these cases, those closer to central power also tend to be more beneficiated, with higher positions and salary.

According to Russo et al. (2012), this relation between Zeus and its vassals represents an exchange dynamic, of which the one who is at the top of the hierarchy will conceive benefits in exchange for power influence. As the power is extremally centralized in the organizations that compose this spectrum, there usually not much space for elaboration of rules and norms. Or, as of cited by Russo et al. (2012), even though rules and norms probably exist, as in any organization, they should change constantly, according to the interests of those in command. As consequence, as says the author, the companies that make up the culture of power spectrum are normally organized through structures that create itself from the establishment and appreciation of its functions as shown in Table 1.

Table 1: Components of the compensation model Based on Russo et al. (2012)

\begin{tabular}{|c|c|c|c|c|}
\hline & Zeus & Apollo & Athena & Dionysus \\
\hline Constructs & $\begin{array}{l}\text { Focus on } \\
\text { individual } \\
\text { relationship }\end{array}$ & $\begin{array}{l}\text { Focus on roles } \\
\text { and rules }\end{array}$ & $\begin{array}{l}\text { Focus on results } \\
\text { and efficiency }\end{array}$ & $\begin{array}{c}\text { Focus on } \\
\text { individuality }\end{array}$ \\
\hline $\begin{array}{c}\text { Base Salary } \\
\text { (SAL) }\end{array}$ & $\begin{array}{l}\text { Emphasis on } \\
\text { person }\end{array}$ & Emphasis on role & $\begin{array}{c}\text { Emphasis on the } \\
\text { person }\end{array}$ & $\begin{array}{l}\text { Emphasis on the } \\
\text { person }\end{array}$ \\
\hline $\begin{array}{l}\text { Evaluation } \\
\text { Criteria and } \\
\text { individual } \\
\text { contribution } \\
\text { (AVA): }\end{array}$ & $\begin{array}{l}\text { Emphasis in } \\
\text { seniority }\end{array}$ & Variable & $\begin{array}{l}\text { Emphasis in } \\
\text { performance }\end{array}$ & $\begin{array}{l}\text { Emphasis in } \\
\text { performance }\end{array}$ \\
\hline $\begin{array}{c}\text { Performance } \\
\text { Indicators (IND) }\end{array}$ & $\begin{array}{l}\text { Emphasis in } \\
\text { individuality }\end{array}$ & Variable & Variable & $\begin{array}{l}\text { Emphasis in } \\
\text { individuality }\end{array}$ \\
\hline $\begin{array}{c}\text { Nature of } \\
\text { Indicators (NAT) }\end{array}$ & $\begin{array}{c}\text { Emphasis on } \\
\text { behavioral factor }\end{array}$ & Variable & $\begin{array}{l}\text { Emphasis on } \\
\text { financial }\end{array}$ & Variable \\
\hline $\begin{array}{c}\text { Goal Difficulty } \\
\text { (MET) }\end{array}$ & Variable & Variable & $\begin{array}{l}\text { Emphasis on } \\
\text { difficult tasks }\end{array}$ & Variable \\
\hline Rewards (REC) & Variable & $\begin{array}{l}\text { Emphasis on } \\
\text { financial }\end{array}$ & $\begin{array}{l}\text { Emphasis on } \\
\text { financial }\end{array}$ & Variable \\
\hline $\begin{array}{l}\text { Organizational } \\
\text { Climate (CLI) }\end{array}$ & Variable & Variable & $\begin{array}{l}\text { Emphasis on bad } \\
\text { by pressure }\end{array}$ & $\begin{array}{l}\text { Emphasis on } \\
\text { excellent }\end{array}$ \\
\hline $\begin{array}{l}\text { Opportunity for } \\
\text { growth and } \\
\text { development } \\
\text { (OPO) }\end{array}$ & Variable & Variable & $\begin{array}{l}\text { Emphasis on } \\
\text { abundant }\end{array}$ & $\begin{array}{l}\text { Emphasis on } \\
\text { abbundant }\end{array}$ \\
\hline $\begin{array}{l}\text { Remuneration } \\
\text { Level (REM) }\end{array}$ & Variable & Variable & $\begin{array}{l}\text { Emphasis on larger } \\
\text { than average } \\
\text { variable income }\end{array}$ & $\begin{array}{l}\text { Emphasis on } \\
\text { larger than } \\
\text { average income }\end{array}$ \\
\hline Equity (EQU) & $\begin{array}{l}\text { Emphasis in } \\
\text { internal } \\
\text { equilibrium }\end{array}$ & $\begin{array}{l}\text { Emphasis in } \\
\text { internal and } \\
\text { external } \\
\text { equilibrium }\end{array}$ & Variable & $\begin{array}{l}\text { Emphasis on } \\
\text { external } \\
\text { equilbrium }\end{array}$ \\
\hline $\begin{array}{l}\text { Composition } \\
\text { (COM) }\end{array}$ & Variable & $\begin{array}{l}\text { Emphasis on } \\
\text { fixed income }\end{array}$ & $\begin{array}{c}\text { Emphasis on } \\
\text { variable income }\end{array}$ & Variable \\
\hline Time (TEM) & $\begin{array}{c}\text { Emphasis in long } \\
\text { term }\end{array}$ & $\begin{array}{c}\text { Emphasis in long } \\
\text { term }\end{array}$ & $\begin{array}{c}\text { Emphasis in short } \\
\text { term }\end{array}$ & $\begin{array}{c}\text { Emphasis in short } \\
\text { term }\end{array}$ \\
\hline
\end{tabular}


In terms of organizational remuneration systems, several authors argue about this, such as Belcher (1974), Milkovich and Newman (1987), Bloom and Milkovich (1996), Plothow (2006). Milkovich and Stevens (2000) traced a timeline of the main remuneration models in force in the United States during each of the main historical and socioeconomic moments experienced in the country in the last century. In view of the strong American influence on the practices adopted in Brazil in the last century, as well as the correlation between moments of crisis or economic strengthening in both countries, this study will be analyzed as a structuring part of the reasoning of the application of remuneration systems. The panorama constructed by the authors makes clear the analysis of how the remuneration structure of each periods portrayed is a reflection of the very worldview of men in each of these periods, as well as of the current economic system and the relationship between the expectations of employees and employers.

According to Batitucci (2000), the main objective of developing strategies in the area of human resources is to make it possible for a company to achieve the results it expects through the development of its employees, who have incentive and motivation plans. To this end, a company must ensure that its staff is as prepared and motivated as possible to deal with an increasingly dynamic and competitive market context. Thus, your employees must be prepared to deal with possible changes, adaptations and, certainly, many obstacles that will be ahead of the company's plans.

The organizational behavior of the organizational actors towards a remuneration system depends on many factors related to the organizational culture. The creation of an own remuneration system can influence organizational individuals so that they develop what is of interest to the organization itself, obviously being a motivational method. When that system is not align with the organizational culture, there are likely to be consequences for achieving the companies objectives (Madhani, 2015).

As a consequence of the remuneration system proposed by the employer, the employee will behave in a more or less creative, more or less proactive and, consequently, more or less productive (Russo; Viana and Hall, 2007), depending on what is proposed. This is because, according to the authors, a person's behavior will always be conditioned according to his level of satisfaction and encouragement in a given context. It is in this scenario that the relevance of studies that aim to make the compensation system as appropriate, fair and clear as possible is inserted, aiming at valuing and encouraging the individual and making the most of its full potential.

\section{METHODOLOGIES}

The research developed in this study is featured as qualitative and descriptive. in terms of data collection a questionnaire was previously elaborated and later applied to the director and others five employees' company. In this manner, the approach adopted was of a Simple Case Study. The company chosen is a digital marketing branch, located in the city of Sao Carlos, state of Sao Paulo. The company's choice for study (DETEC) was made because the company was recently created, and the authors and partners believe that the majority of the processes are still being elaborated, as well as the organizational culture's company was being emerged.

According to Yin (2001) the case study allows an investigation to preserve the holistic characteristics and significant effects of real life events - such as individual life cycles, organizational and administrative processes, changes occurring in regions urban relations, international relations and the maturation of some sectors. he case study has many of the techniques used by historical research, but adds two sources of evidence that usually are not included in a historian's repertoire: direct observation and systematic series of interviews.

In order to expand the study by Araujo (2012), who also applied and carried out a case study based on the study by Russo et al (2012), three initiatives were proposed. The first of these was trying to carry out the case study in a company that differed significantly, with regard to the present organizational culture, from the company analyzed by Araujo (Petros). Then a second questionnaire was applied, but this time based on Hofstede's cultural 
definitions so that we could better understand the organizational culture of DETEC and so that we could also compare the analyzes of the organizational culture present in the company according to the models of Charles Handy and Hofstede, finding possible correlations or differences.

Finally, it was proposed not only to analyze the results and present the differences, but also to propose possible changes to the remuneration model currently used by the company, considering that the partners of DETEC showed interest in the presentation of such proposals, making it clear that were willing to make such changes if they agreed with the results of the study.

The questionnaire used to identify which of Charles Handy's cultural typologies the company most resembles was the one elaborated by the study by Russo et al. (2012). This questionnaire was reconstructed in a spreadsheet in Google Sheets by the author, so that DETEC members could access and answer them more easily.

The application contains 9 questions, which are asked in two different contexts. First, the questions were asked so that the respondent could answer according to what happens today at DETEC. Subsequently, they were repeated, but this time, the interviewee should respond in the sense of how he thinks it should happen at DETEC, and not how it really is. With that, it was possible to compare the reality of the company with what its members really expect to happen or that, at least, would like to be changed according to their own convictions about the company's culture. For each question there are 4 possible answers.

Each answer represents one our different cultural typologies by Charles Handy. The interviewee must not only indicate a correct answer, but should list them, according to their order of priority, as shown in Table 2:

Table 2. Questionnaire Model

\begin{tabular}{lc}
\hline \multicolumn{1}{c}{ 1. For the company, a good boss is: } & Order \\
\hline a) Decided, firm, loyal but just. Is protecting, generous, and indulgent with loyal subordinates & 3 \\
\hline b) Impersonal and correct, evading of taking advantage of its authority. Requires from & 2 \\
subordinates only what is required by the formal system & 4 \\
\hline c) Egalitarian and influenceable on subjects relative to te task. Uses its authority to obtain \\
the necessary resources for the continuation of the task
\end{tabular}

Following the example above (Table 2), the interviewee chose answer " $\mathrm{D}$ " as most adequate and " $A$ " as least adequate for the question asked. The correlation between the answers and Handy's typological cultures is structured as follows: Power Culture - Zeus (Answer "A"); Role Culture - Apollo (Answer "B"); Task Culture - Athena (Answer "C") and Person Culture - Dionysus (Answer “ $D^{\prime \prime}$ ). The other eight sentences that complete the research protocol are:

2. For Detec a good subordinate is...

3. For Detec a good employee prioritizes...

4. People who are successful at Detec is...

5. Detec treats the individual as...

6. At Detec people are influenced and controlled by...

7. At Detec it is legitimate for one person to control the activities of another if...

8. At Detec the bases for the distribution of tasks are...

9. At Detec the competition suits to ...

The definition of which typological culture by Charles Handy represents the organization culture presented in the company according to the answers of the census was obtained in a simple manner. Because the answers were supposed to be in order of priority, from 1 to 4 , 
the typology that had the lower score in the sum of all results would be the one that is most present in the organizational culture of the company. On the other hand, the typology that obtained the highest absolute value in the sum of its results would be the one that is less presented in the organizational culture of the company. Always remembering the organizational culture of a company must be the result of the influence of more than one cultural typology, as Charles Handy himself recalled. The aim of this study was to identify the typologies that most represented the influences on the company's culture.

Lastly, with the result of the research through the census and considering the table from the study from Russo et al. (2012) that compare each of Charles Handy's typologies with each of the aspects of remuneration model of a company, it was compared the current remuneration model with the ideal remuneration model proposed by the study. Corresponding to the analysis, it was possible to propose some new practices to be adopted by the company with the purpose to making the remuneration model of the company more adherent to its organizational culture.

\section{RESULTS}

\subsection{Company Characterization}

The company chosen for the study is small and located in Sao Carlos - SP, and operates in digital marketing. Its name is DETEC Digital Entrepreneurship. The company was funded in the beginning of 2020 by two former students of EESC - USP, one of them graduated in Mechanical Production Engineering and the other, in Material and Manufacture Engineering. Even though the company was funded recently, both already worked with digital marketing for 4 years and decided to united to fund their own company. Today, DETEC has 9 employees (including the partners), with all of them having prior experience in Digital Marketing.

The main activity at DETEC is providing digital marketing/divulgation to clients at digital products branch (online courses). The partnerships ate formed between DETEC and the owners of the online courses. The services provided by the company are advertised in the platform of the largest social medias, such as Google, Facebook, YouTube, Instagram, and others, with the objective to sell these products and receiving, in exchange, a commission for the number os sales generated. Furthermore, DETEC also charges a fixed fee from each client. Currently, the company provides services for 14 clients. Amongst them, there are online courses on languages, organic agriculture and sustainability, accounting, finance market and oratory.

\subsection{Description of current model of organization and remuneration model}

The company DETEC does not, and as of now, does not pretend to having a fixed office. All of its employees work in home-office regimen. The hours are also completely flexible, that is, each employee can decide in which hours they chose to complete workload. The partners believe in the viability of this model to small companies (up to 25 employees, according to them). The model of communication adopted by the company is asynchronous, with the purpose of practices and methods for optimizing the communication based on the assumption that the people involved may not be at the same place or even working at the same hours. In the asynchronous communication model, according to the partners, all employees must be adapted to dealing with wait time for a response. With that, they tend to fill their e-mails with the most content as possible. Besides that, Weekly area meetings and also between them, for the constant alignment of all parts involved.

The current remuneration model of the company is based of legal person (LP) contract. Each employee of the company is an individual micro entrepreneur. Each role receives a fixed salary, which is also below Market average. The coordinators receive, for example, three thousand each month. The same happens for the partners, receiving a fixed amount each month. The purpose is that the remaining gets invested by the company. Even so, DETEC 
adopts as a practice the distribution of trimestral bonus to its employees, according to overall profit generated and by the position occupied by each member.

The bonus is composed by a portion that results from individual performance and another portion that results from overall profit of the company. For the individual portion of the bonus, it is taken in consideration the contribution and the individual performance of each contributor according to progress/result of their projects. In this scenario, $8 \%$ of the profit of each profit is equally divided between all people involved, regardless their role or function. Only the interns do not receive the bonus, if there are any

For the general portion of the bonus, the calculation is effectuated based on trimestral overall profit of the company. Currently, $15 \%$ of this profit is divided and distributed as bonus to DETEC employees. In this system, although, Other than the individual portion, the profit is not divided equally. Each of the hierarchical levels has a ponderosity in the distribution. The intern analysts have a 1 ponderosity, if there are any, the analysts, 2 ponderosity, coordinators, three, and partners, 4. Currently, this is the system adopted for the distribution of the bonus at DETEC.

Through the analysis of the results of the census sent to the partners and coordinators of DETEC, it is possible to infer that the cultural typologies mostly present in the copany, are, firstly, Person Culture (Dionysus) and following, Task Culture (Athena), as illustrated in the Table 3 that follows.

Table 3: Questionnaire Results

\begin{tabular}{ccc}
\hline CATEGORY & TYPOLOGY & ABSOLUTE RESULT \\
\hline A & Power Culture (Zeus) & 265 \\
\hline B & Role Culture (Apollo) & 208 \\
\hline C & Task Culture (Athena) & 131 \\
\hline D & Person Culture (Dionysus) & 116 \\
\hline
\end{tabular}

As explained previously, DETEC is a company that has one of its main purposes to construct and provide a work environment in a startup like frame. The partners encourage the establishment of a dynamical work environment that conceives a great autonomy to its employees. For that, it is coherent that the organizational culture of the company strays apart from Power and Role cultures from Charles Handy, seen that they are normally associated with large sizes companies, already very well structures and that tend to encourage the establishment of a more stable and predictable work environment.

The difference of the sum between Task Culture and Person Culture was not large, which indicates that imports aspects of each typology must be present in the day-to-day of the company. On the other hand, the sum of Role Culture and Power Culture were far apart from the other two cultures, therefore, we can assume that the aspects of organizational culture at DETEC are further apart of the characteristics present in these two cultures.

All of the employees - even the partners- of DETEC are young and recently graduated. The two founding partners concluded their graduation course at EESC less than 4 years ago. The company provides services at Digital Marketing and no one at the company has formation in the marketing area. A great obstacle DETEC faces is to hire young and flexible people that are able to work in areas in which they have no prior technical knowledge. Besides that, the partners hope that the employees can deliver good results as early as possible. In this context, it is coherent that the organizational culture at the company values autonomy and individual work, seeking encouraging its employees to be flexible, dynamical and innovative.

These characteristics are strictly tied to the Perons and Taks Cultures from Charles Handy. At the Dionysus Culture (Person) the focus is on the employee, individually, in a way that a control from high management barely exists and that the autonomy is the main characteristic of the company. As a consequence, the employees that show good results receive great rewards. In the Athena Culture (Task), the autonomy of each worker is also present in a 
highlighted manner, but, in this case, the leaderships must be present to help the employees of the company so that they achieve desired results. According to the questionnaire, the Person Culture is the one most present ate DETEC, and we seek to compare the current remuneration model at the company with the ideal, for this typology, based on Russo et al. (2012). Even it was taken into consideration the fact that the Task Culture is also greatly present in the organizational culture of the company.

Through the application of the census, it was identified the interest of the partners and coordinators at DETEC in formulating the organizational culture of the company based on the Person and Task Cultures, from Handy's typology. With that, it was possible to analyse each aspects that compose the remuneration model, seeking that the organization culture and wage structure are in tune, and consequently, with the interests of the company.

- Base Salary (SAL): Role vs Personal Factors: It was evaluated and considered that the currently salary at DETEC is much more related to the hierarchical position occupied by the employee than its personal and individual competences. There is not, for example, any differentiation in salary between workers with the same position. According to Russo et al. (2012), so much in Person culture as in Task culture, the emphasis of this payroll component should be focused on the personal qualifications of each person. More qualified employees should receive a higher salary, in a way that would encourage the other workers to qualify themselves be able to negotiate a higher payroll at the company. In companies that use this system, the realization of specialization courses by an employee can justify, for example, an increase in payroll, without needing to be promoted. As proposal, we recommended DETEC the formulation of a model that differentiates the salary earned by each employee, according to the qualifications of each one, and that the grant of higher payrolls should not bet strictly tied to an increase in hierarchical level. This should make the work environment more dynamical and the workers more encouraged to qualify themselves and become more proactive. This should also make DETEC attract more talents to the staff, negotiating individually their salaries according to the interests of the company and return expectance.

- Evaluation Criteria and individual contribution (AVA): The way DETEC evaluates each employees' contribution is focused on individual performance of each one, not minding the hierarchy level or the role the person occupies. Each worker has its own goals and the result is evaluated in the sense of obtaining or not the goal. The evaluation of the contribution turned to the results of each individual (and not the role) is in agreement with what Russo et al. (2012) sees as coherent for the cultures of People and Task.

- Performance indicators (IND): DETEC has the practice to institute and accompany the performance indicators for each project. Each one is composed by a team responsible for accomplishing it, with leadership roles and analysts. According to the partners, the objective is to encourage team work and collaboration between its employees through the establishment of a common objective. However, Russo et al. (2012) indicates that, for companies with the Person (Dionysus) culture, it is important that goals be individual. According to the authors, in an environment in which the work should be supervised lightly and the employees with a greater autonomy to accomplish the tasks, it is important for leaders to measure each worker with individual performance indicators. Otherwise, a bad performance by the employees can be overlook by the good team work and the partners would probably take longer to identify the problem if lower than expected. Besides that, individual goals (attached to good rewards for good performance) should make so that the employees are encouraged to use its autonomy wisely, and produce more for the company. It is recommended that DETEC switched its system of goals by project for a new system that the overall goals of the projects be divided into smaller goals distributed between the employees at that project. Lastly, it is also recommended the maintenance of individual goals already existent in the company that measure how much each works is acting according to the organizational culture proposed by the 
organization. This is a coherent and healthy practice that fit the Person Culture typology by Charles Handy.

- Indicator Nature (NAT): the performance indicators utilized by DETEC vary between financial indicators (project performance) as well as qualitative indicators (cultural fit). According to Russo et al. (2012), companies that fit Handy's Person Culture typology should have variable indicators and, for companies that fit the Task Culture, mostly financial indicators. It was observed that the nature of the indicators at DETEC is in agreement of what was proposed by Russo et al. (2012) for the remuneration model of the company in tune with its current organizational culture.

- Goals Difficulty (MET): the performance goals at DETEC are hard. According to the partners of the company, as stated before, it is a way to maintain the workers motivated and algo ensure that they complete the workload. This is directly tied to the autonomy conceived to the workers at the company. According to Russo et al. (2012), hard foals applied to companies that fit the Person and Task culture justifies itself justly as a motivational and incentive points so that the workers utilize their autonomy as best as possible. In this way, goals difficulty at DETEC are in agreement with its organizational culture.

- Rewards (REC): Currently the remuneration model offered by DETEC to its employees is composed by financial rewards, and not offering any other kind of rewards, such as transportation. According to Russo et al. (2012), the type of reward offered by companies that fit the Person culture typology can be variable, but in companies that fit the Task culture, the benefits should mostly be financial. Therefore, we found that the reward policy applied at DETEC is in agreement with its organizational culture.

- Organizational Climate (CLI): The organizational climate at DETEC is excellent, according to its partners and coordinators. The company is composed mostly by friend and also, whoever joins creates friendship laces with the others quickly. The meetings are usually relaxed and employees are encouraged to know each other better through conversations or happy hours. According to Russo et al. (2012), the organizational climate predominant in companies that fit the Person Culture typology should be excellent, so that the employees feel more encouraged and motivated. A good climate can contribute also so that the workers develop a sense of belonging to the group with common objectives and in which the people collaborate with each other. All of that should counterbalance the individuality of the goals and escort of the results, collaborating for the establishment of a harmonious and healthy environment.

- Growth and Development Opportunity: the opportunities of growth and development ate DETEC are abundant. The company was funded recently and is already in a great growth period. Only in the year of 2020 three selective processes were applied for the hiring of new member. In this way, new projects are being implemented constantly according to the demand of new clients and, this ways, new cargos and opportunities also arise constantly. According to the partners, an employee that presents a good and consistent performance certainly should get new opportunities in less than a year. This dynamic is in agreement with what Russo et al. (2012) stipulates in his study for companies that are in the Task and Person culture typologies by Charles Hand. According to the authors, the opportunities for growth in their companies should always be abundant.

- Remuneration Level (REM): the remuneration level offered by DETEC today is at the same level offered by companies in the same branch in the area. According to the partners, the work benefits at DETEC do not fix themselves only to payroll, but also to the flexibility of work hours (even more so for interns) and the home-office regimen, that can be interesting for some people. One of the workers at DETEC decided, for example, to live at the beach since the beginning of 2020. According to the study realized by Russo et al. (2012), the level of salary offered by companies that fit in Person and Task cultures should be above market. That is because of the dynamics having more risk and instability in an environment such as DETEC. With the same payroll, for example, is more beneficial for 
an employee to stay in an company that has more stability. Because of that, it is recommended that DETEC studies the possibility of increasing the payroll to its workers, so it becomes above market average.

- $\quad$ Equity (EQU): currently, DETEC seeks to equate the level of salary as offered by competitor companies in Sao Carlo. Therefore, there is a clear emphasis in external equilibrium and that is justly in agreement with what is proposed by Russo et al. (2012) for companies that fit the Person culture typology. The payroll level offered by the company should be competitive with what is offered by its competitors, even more so in the same city.

- $\quad$ Composition (COM): the payroll offered by DETEC and all its hierarchic levels are currently composed by a fixed portion and a variable portion. As of today, the fixed portion represents the majority of the payroll. According to Russo et al. (2012), however, for companies that fit Person and Tasks culture typologies, the emphasis in variable remuneration should prevail. That is strictly tied to the autonomy to the employees at the company. In the DETEC case, for example, all employees work in the home-office regimen. In this context, a fixed remuneration can make it so the workers feel comfortable and be less productive for the company. On the other hand, a model with emphasis on commission or bonus for individual results should make it so that the workers engage more and utilize their autonomy for more productivity at the company. In this way, it is proposed for DETEC that it adapts its system to give a bigger emphasis in the variable portion of the remuneration.

- $\quad$ TIME (TEM): The strategies for realization of processes and growth of DETEC are turned for the short term. According to the partners, that explains itself, firstly, because the company was created recently and with the objective to utilize the moment to grow, achieving new clients and beginning new projects when possible, according to the capacity of the company. On the other hand, the majority of the employees at DETEC are recent graduates and it is common for recent graduate students at Sao Carlos to seek opportunities in other places. For that, according to the partners, the company should always be prepared to a staff loss situation.

- On one hand, the partners developed a system of an agile selective process and that contemplates the necessities of the company. On the other, focusing in short term objectives is also one of the practices adopted by DETEC of dealing with this situation, given that, this way, there is lesser chance to lose key employees during the following of a project. According to the study realized by Russo et al. (2012), companies that fit the Person and Task typologies should, in fact, focus on short term goals. We found, therefore, that the practices adopted by DETED currently are coherent with the organizational culture of the company.

\section{FINAL CONSIDERATIONS}

Identified the main cultural typologies at DETEC, an analysis of the structure and remuneration model utilized by the company was applied. In parallel, the study by Russo et al. (2012) was presented, which correlates the cultural typologies by Charles Handy with an ideal remuneration model for each of them. With that, it was possible to compare the remuneration system adopted by DETEC with the one that would be ideal for the company, according to the study by Russo et al. (2012).

Two main suggestions of this study for the adequation of the remuneration model adopted by DETEC were made. The first one is that the company should seek to increase the variable portion on the payroll of its employees. Because the people that work at the company have great autonomy, working remotely and being able to chose work hours, adopting a system that prioritizes variable portion of the salary is important so that the workers feel motivates to produce more, seeking a higher remuneration. Otherwise, with a good level of fixed remuneration, the workers can become less productive and comfortable.

The second suggestion of this study is that the partners of the company seek ways to increase to the payroll level of the company. According to the study realized by Russo et al. 
(2012), companies that fit Persons and Task culture typologies should offer salaries above the market average to its workers, given that these companies are associated with greater risk and instability, when compared to traditional companies. The fact that the salary is composed mostly by a variable portion, for example, is a risk for a worker. Therefore, to be worth it, the payroll level should be above market average. Currently, the salary offered by DETEC is in the average of what is offered by companies on the same sector in the region of Sao Carlos. Other suggestions appointed by this study to the partners and executives of DETED were the adequation of goal system for the company, seeking to prioritizing individual goals instead of collective goals, and the differentiation of fixed portions of the salaries taking into consideration personal qualifications of each employee.

Lastly, it was found that the majority of the payroll components already adopted by DETEC are in an agreement of what Russo et al. (2012) proposes as being ideal for companies that fit the Person and Task culture typologies. As highlights, were pointed out a good organizational climate in the company, with collaboration and trust between its workers, with the objectives focused on short term, bearing in mind the lack of predictability in the long term of the current market and the fact that the company has been recently created.

In practical terms these cultural typologies are related to companies that have less hierarchical and bureaucratic structures, and that prioritize aspects such as the autonomy and freedom of their employees. In the case of DETEC, it was possible to verify the strong correlation between the valuation of these elements and some of the main work practices adopted by the company, such as flexible working hours, remote work (home-office) and performance evaluation through goals of performance and result. In this way, it is perceived that the remuneration system is aligned with the cultural characteristics of the organization, which allows better conditions for the management of human and productive resources.

This research for being a specific case study in a small digital marketing company cannot be generalized to other contexts and sectors of activity. The pandemic situation also caused limitations in the development of the research, as it was not possible to develop face-to-face interviews and a method of observing the workspace, in order to verify other cultural characteristics of the organization. The possibility of using other research methods could lead to deeper results and considerations.

\section{REFERENCES}

Ancillo, A.L., Núñez, M. T. del Val and Gavrila, S.G. (2020), “Workplace change within the COVID-19 context: a grounded theory approach", Economic Research-Ekonomska Istraživanja, pp. 1-21.

Araujo, L.G.S. (2012), Cultura Organizacional e Estratégias de Remuneração: um Estudo de Caso, Dissertação de Mestrado em Administração de Empresas, Pontifícia Universidade Católica do Rio de Janeiro, Rio de Janeiro, RJ.

Batitucci, M.D. (2000), A Função do RH no Terceiro Milênio, Qulaitymark, Rio de Janeiro.

Belcher, D.W. (1974), Compensation Administration. Prentice-Hall Inc., New Jersey.

Bloom, M.C. and Milkovich, G.T. (1996), "Issues in managerial compensation research", Journal of Organizational Behavior (1986-1998).

Bourantas, D., Anagnostelis, J., Mantes, Y. et al. (1990), "Culture gap in greek management", Organization Studies, vol. 11, pp. 261-283.

Freitas, M.E. (1991), Cultura Organizacional: Formação, Tipologias e Impactos, São Paulo.

Freitas, M.E. (2000), "A questão do imaginário e a fronteira entre cultura organizacional e a psicanálise", in Motta, F., and Freitas, M.E., Vida Psíquica e Organização, Ed. FGV, Rio de Janeiro.

Gomide Júnior, S. and Martins, M.C. (1997), "Os deuses da administração: construção e validação de quatro escalas para medida de cultura organizacional", Psicologia: Teoria e Pesquisa, vol. 13, no. 3, pp. 311-6.

Handy, C. (1980), The Gods of Management, Pan, London.

Handy, C. (2003), Deuses da Administração, $3^{a}$ ed., Ed. Saraiva, São Paulo. 
Hofstede, G. (2001), Culture's consequences: comparing values, behaviors, institutions and organizations across nations. California.

Ludolf, N.V.-E., Silva, M.C., Gomes, C.F.S. et al. (2017), "The organizational culture and values alignment management importance for successful business", Brazilian Journal of Operations \& Production Management, Vol. 14, No. 2, pp. 272-80.

Madhani, P.M. (2015), "Aligning compensation systems with organization culture", Compensation and Benefits Review, Vol. 17, pp. 1-13.

Milkovich, G.T. and Newman, J.M. (1987), Compensation, 2ª ed., Business Publications, Texas.

Milkovich, G.T. and Stevens, J. (2000), "100 years of change", ACA Journal, Vol. 9, No. 1, pp. 6-26.

Plothow, C.B. (2006), Fatores Contingenciais à Estratégia de Remuneração da Força de Venda, Dissertação de Mestrado em Administração, Faculdade de Economia e Administração, Universidade de São Paulo, São Paulo, SP.

Russo, G.M., Tomei, P.A., Linhares, A.J.B. et al. (2012), “Correlacionando tipos de cultura organizacional com estratégias de remuneração utilizando a tipologia de Charles Handy", Revista Eletrônica de Administração, Vol. 73, No. 3, pp. 651-680.

Russo, S.; Viana, J.; Hall, R. (2007), Remuneração variável: uma ferramenta estratégia para as organizações. Universidade Federal da Grande Dourados, Dourados, MS.

Schein, E.H. (1985), Organizational Culture and Leadership: A Dynamic View, Jossey-Bass, Hoboken.

Vyas, L. and Butakhieo, N. (2021), "The impact of working from home during COVID-19 on work and life domains: an exploratory study on Hong Kong", Policy Design and Practice., Vol. 4, No. 1, pp. 59-76.

Yin, R. K. (2001), Estudo de caso: planejamento e métodos, $2^{\text {a }}$ ed., Bookman, Porto Alegre.

Author contributions: All the authors contributed equally to this paper. 